\title{
SYTUACJA UCHODŹCóW WEWNĘTRZNYCH NA UKRAINIE W ŚWIETLE REGULACJI PRAWNO-MIĘDZYNARODOWYCH
}

\section{Wprowadzenie}

Po wydarzeniach nazywanych „rewolucją godności”, które miały miejsce na Ukrainie pomiędzy listopadem 2013 r. a lutym 2014 r., doszło do aneksji Krymu przez Rosję, a następnie do konfliktu zbrojnego pomiędzy prorosyjskimi rebeliantami a siłami ukraińskimi na wschodzie tego państwa - w obwodach donieckim i ługańskim. W związku z tym, na terytorium Ukrainy pojawiła się nowa, wcześniej właściwie nieznana temu państwu ${ }^{1}$, kategoria uchodźców, zwanych uchodźcami wewnętrznymi lub osobami wewnętrznie przesiedlonymi.

Niniejsza analiza wpisuje się w nurt rozważań na temat wpływu regulacji prawno-międzynarodowych na szanowanie praw człowieka w sferze wewnętrznej państw. Celem opracowania jest ukazanie oddziaływania prawa międzynarodowego o charakterze zarówno hard law jak i soft law na pewne rozwiązania prawne przyjęte na Ukrainie. In concreto chodzi o rozwiązania wewnętrznego prawa ukraińskiego, które zostały wymuszone wyżej przywołanymi niepokojącymi faktami odnoszącymi się do terytorium tego państwa.

* Dr hab., Uniwersytet Jagielloński; e-mail: brygida.kuzniak@uj.edu.pl.

* Dr, Lwowski Narodowy Uniwersytet im. Iwana Franki; e-mail: izeman@ukr.net.

1 Tu warto zaznaczyć, że w wyniku katastrofy w 1986 r. w Czernobylu (wówczas jeszcze terytorium ZSRR) został skażony radioaktywnie obszar rozciągający się na około 500 km wokół Czernobyla i z tego powodu około 200 tysięcy osób zostało zmuszonych do zmiany miejsca zamieszkania. Była to sytuacja podobna do przesiedlenia wewnętrznego, choć kwalifikuje się ją także jako masową ewakuację z niebezpiecznego regionu. 
W pierwszej części analizy skrótowo przywołano (w charakterze tła dalszych rozważań) wybrane zagadnienia z zakresu prawno-międzynarodowej ochrony uchodźców oraz zarysowano problematykę uchodźców wewnętrznych. W drugiej części przedstawiono skalę wspomnianego zjawiska, a w szczególności dane statystyczne dotyczące Ukrainy. W trzeciej części zaprezentowano odpowiednie rozwiązania prawa ukraińskiego, a następnie całość opracowania zwieńczono konkluzjami.

\section{Uchodźcy a uchodźcy wewnętrzni - zarys problemu}

Istnieje ścisły związek między problemem uchodźców oraz uchodźców wewnętrznych a prawami człowieka². Już w 1948 r. w Powszechnej Deklaracji Praw Człowieka, w jej art. 2 sformułowano zasadę niedyskryminacji ${ }^{3}$, zaś następnie z zasady niedyskryminacji zapożyczono kryteria na użytek konstruowania definicji uchodźcy zawartej w Konwencji dotyczącej statusu uchodźców z 1951 r. ${ }^{4}$ (do szczególnie istotnych postanowień tej konwencji należy zasada non-refoulement $\left.{ }^{5}\right)$.

2 Zob. m.in. M.M. Сірант, Біженці та внутрішньо переміщені особи: співвідношення понять, „Митна справа” 2015, nr 2, s. 154; В.І. Надрага, Проблеми вилущеної внутрішньої міграції населення в контексті концеепції «суспільства ризику”, „Український соціум" 2015, nr 1, s. 137.

${ }^{3}$ „Każdy człowiek posiada wszystkie prawa i wolności zawarte w niniejszej Deklaracji bez względu na jakiekolwiek różnice rasy, koloru, płci, języka, wyznania, poglądów politycznych i innych, narodowości, pochodzenia społecznego, majątku, urodzenia lub jakiegokolwiek innego stanu. Nie wolno ponadto czynić żadnej różnicy w zależności od sytuacji politycznej, prawnej lub międzynarodowej kraju lub obszaru, do którego dana osoba przynależy, bez względu na to, czy dany kraj lub obszar jest niepodległy, czy też podlega systemowi powiernictwa, nie rządzi się samodzielnie lub jest w jakikolwiek sposób ograniczony w swej niepodległości", tekst Deklaracji na stronie internetowej Ośrodka informacji ONZ w Warszawie, http://www.unic.un.org.pl/prawa_czlowieka/dok_powszechna_deklaracja.php [dostęp: 21.02.2017 r.].

4 Konwencja dotycząca statusu uchodźców sporządzona w Genewie dnia 28 lipca 1951 r., Dz. U. z 1991 r. Nr 119, poz. 515 i 517, „Artykuł 1. [...] termin „uchodźca” stosuje się do osoby, która [...] na skutek uzasadnionej obawy przed prześladowaniem z powodu swojej rasy, religii, narodowości, przynależności do określonej grupy społecznej lub z powodu przekonań politycznych przebywa poza granicami państwa, którego jest obywatelem, i nie może lub nie chce z powodu tych obaw korzystać z ochrony tego państwa, albo która nie ma żadnego obywatelstwa i znajdując się na skutek podobnych zdarzeń, poza państwem swojego dawnego stałego zamieszkania nie może lub nie chce z powodu tych obaw powrócić do tego państwa".

5 "Art. 33. Zakaz wydalania lub zawracania. 1. Żadne Umawiające się Państwo nie wydali lub nie zawróci w żaden sposób uchodźcy do granicy terytoriów, gdzie jego życiu lub wolności zagrażałoby niebezpieczeństwo ze względu na jego rasę, religię, obywatelstwo, przynależność do określonej grupy społecznej lub przekonania politycz- 
Tymczasem w grudniu 1949 r. mocą uchwały Zgromadzenia Ogólnego ONZ powstał Urząd Wysokiego Komisarza Narodów Zjednoczonych ds. Uchodźców (United Nations High Commissioner for Refugees - UNHCR) ${ }^{6}$, zaś w 1957 r. Zgromadzenie uznało, iż problem uchodźctwa ma charakter globalny ${ }^{7}$.

Z kolei, w połowie lat 80. XX w., w związku z tragiczną sytuacją Etiopczyków, dostrzeżono na arenie międzynarodowej problem uchodźctwa wewnętrznego, kierując $w$ tę stronę niezbędną pomoc humanitarną, a następnie podczas konfliktu bałkańskiego w latach 90. Sadako Ogata, Wysoki Komisarz Narodów Zjednoczonych ds. Uchodźców, postanowiła, choć z formalnego punktu widzenia poza swym mandatem, objąć ochroną i tę kategorię uchodźców (Internally Displaced Persons - IDPs) ${ }^{8}$. W dalszym rozwoju odpowiednich procedur w ramach ONZ, na wniosek Komisji Praw Człowieka w 1992 r. działalność rozpoczął Przedstawiciel Sekretarza Generalnego ONZ ds. Praw Człowieka Osób Wewnętrznie Przesiedlonych (Representative of the Secretary-General on the Human Rights of Internally Displaced Persons). Aktywność skoncentrowano w szczególności na opracowaniu odpowiednich normatywnych i instytucjonalnych ram ochrony i pomocy uchodźcom wewnętrznym oraz podejmowaniu misji krajowych w dia$\log \mathrm{u}$ z rządami i innymi zainteresowanymi stronami ${ }^{9}$. Z czasem wyżej przywołaną funkcję nazwano Specjalnym Sprawozdawcą ds. Praw Człowieka Osób Wewnętrznie Przesiedlonych (Special Rapporteur on the Human

ne. 2. Nie może powoływać się jednakże na dobrodziejstwo niniejszego postanowienia uchodźca, co do którego istnieją podstawy, aby uznać go za groźnego dla bezpieczeństwa państwa, w którym się on znajduje, lub który będąc skazanym prawomocnym wyrokiem za szczególnie poważne zbrodnie stanowi niebezpieczeństwo dla społeczeństwa tego państwa".

6 Rezolucja Zgromadzenia Ogólnego ONZ nr 319 (IV) z 3.12 .1949 r.

7 Rezolucja Zgromadzenia Ogólnego ONZ nr 1166 (XII) z 26.11.1957 r.; na temat UNHCR, zob. więcej I. Woyciechowska, Uchodźcy, [w:] J. Symonides (red.), Organizacja Narodów Zjednoczonych. Bilans i perspektywy, Warszawa 2006, s. 353-359.

8 Informacje na oficjalnej stronie UNHCR dotyczące IDPs, http://www.unhcr.org/internally-displaced-people.html [dostęp: 13.03.2017 r.]; informacje na stronie: tolerancja.pl (wydawca Fundacja Kultury Chrześcijańskiej ZNAK), http://www.tolerancja.pl/?o-miedzynarodowej-ochronie-uchodzcow,300,,2 [dostęp: 13.03 .2017 r.]; zob. również: D. Heidrich-Hamera, Międzynarodowa ochrona uchodźców wewnętrznych. Aspekty prawne i praktyka, Warszawa 2005, s. 40; I. Woyciechowska, Uchodźcy, s. 360; M. Maciąg, Bonpoc ^uи, перемещенных внутри страны, в современном мире и стратегии его рещения, [w:] B. Kuźniak (red.), Wybrane zagadnienia współczesnego prawa międzynarodowego publicznego ze szczególnym uwzględnieniem niektórych aspektów funkcjonowania organizacji międzynarodowych, Kraków 2016, s. 62-70.

9 Zob. United Nations Commission on Human Rights, Report of the Representative of the Secretary-General, Mr. Francis M. Deng, submitted pursuant to Commission resolution 1997/39. Addendum: Guiding Principles on Internal Displacement, E/CN.4/1998/53/Add, http://www.un-documents.net/gpid.htm [dostęp: 27.01.2018 r.]. 
Rights of Internally Displaced Persons), przy czym można powiedzieć, że zakres działania w jej wykonywaniu nie doznał zmian. Dla udzielania pomocy Specjalnemu Sprawozdawcy, w 1994 r. został wdrożony tzw. Broogings Projekt (później Broogings-Bern Projekt), który obejmował publiczno-prywatną współpracę. W przeciągu 20 lat przeprowadzono w ten sposób monitoring problemów uchodźców wewnętrznych w skali świata ${ }^{10}$. Obecnie, tj. od listopada 2016 r. mandat Sprawozdawcy posiada Cecilia Jimenez-Damary - prawniczka specjalizująca się $\mathrm{w}$ prawach człowieka i prawie humanitarnym, w tym w szczególności w kwestiach migracji ${ }^{11}$. Sprawy uchodźców wewnętrznych, oprócz tego, że zajmuje się nimi UNHCR oraz Specjalny Sprawozdawca, pozostają jednocześnie w kręgu zainteresowania także takich struktur jak: Rada Praw Człowieka ${ }^{12}$, Wysoki Komisarz NZ ds. Praw Człowieka, Program NZ ds. Rozwoju (UNDP), Fundusz NZ na rzecz Dzieci (UNICEF), Światowy Program Żywnościowy (WFP), Światowa Organizacja Zdrowia $(W H O)^{13}$.

Problem udzielania ochrony o charakterze międzynarodowym osobom wewnętrznie przesiedlonym jest skomplikowany, ponieważ odpowiednia pomoc związana jest zazwyczaj z podejmowaniem działań na terytorium danego państwa, a to bywa odbierane jako interwencja w sprawy wewnętrzne. Nie sposób jednak w ogóle zaniechać reakcji, bowiem sytuacja IDPs jest łudząco podobna do sytuacji uchodźców zdefiniowanych postanowieniami Konwencji z 1951 r., z tą różnicą, iż nie dochodzi do przekroczenia przez takie osoby granicy państwa ${ }^{14}$. Szczególnie ważna jest tutaj podwójna natura działań i zobowiązań dotyczących tej kategorii osób. $Z$ jednej strony na każdym państwie ciążą wewnętrzne i prawno-międzynarodowe zobowiązania przestrzegania praw człowieka na swoim terytorium. Z drugiej strony społeczność międzynarodowa bierze jednak na siebie dodatkowe funkcje $\mathrm{w}$ zakresie wspierania osób wewnętrznie przesiedlonych ${ }^{15}$.

10 Zob. K.O. Крахмальова, Правове забезпечення статусу внутрішньо переміщених осіб в Украйні, Науковий вісник Херсонського державного університету, „Серія Юридичні науки" 2016, t. 2, s. 44.

11 United Nations Human Rights Office of the High Commissioner, Special Rapporteur on the Human Rights of Internally Displaced Persons, http://www.ohchr.org/EN/Issues/IDPersons/Pages/IDPersonsIndex.aspx [dostęp: 13.03.2017 r.].

12 Rada (United Nations Human Rights Council) zastąpiła Komisję Praw Człowieka (United Nations Commission on Human Rights) na mocy rezolucji Zgromadzenia Ogólnego ONZ przyjętej 15 marca 2006 r., Resolution adopted by the General Assembly on 15 March 2006, 60/251. Human Rights Council, Resolution A/RES/60/251.

13 Zob. I. Woyciechowska, Uchodźcy, s. 360.

14 Zob. D. Heidrich-Hamera, Międzynarodowa ochrona uchodźców wewnętrznych, s. 41.

15 W tym miejscu warto podkreślić, że art. 13. Powszechnej Deklaracji Praw Człowieka stanowi: „Każdy człowiek ma prawo swobodnego poruszania się i wyboru miej- 
Nie istnieje prawno-międzynarodowy akt typu hard law, który normowałby sytuację IDPS, niemniej Francis M. Deng - osoba, która jako pierwsza pełniła funkcję Przedstawiciela Sekretarza Generalnego ONZ ds. Praw Człowieka Osób Wewnętrznie Przesiedlonych - doprowadził do opracowania przez międzynarodową grupę ekspertów z zakresu prawa międzynarodowego istotnego aktu typu soft law ${ }^{16}$, a mianowicie Wiodących zasad przesiedleń wewnątrzpaństwowych (Guiding Principles on Internal Displacement $)^{17}$. Dokument ten nie ma charakteru wiążącego, niemniej, podobnie jak sama funkcja Specjalnego Sprawozdawcy ds. Praw Człowieka Osób Wewnętrznie Przesiedlonych ${ }^{18}$, bywa akceptowany przez władze państw borykających się z problemem uchodźców wewnętrznych $^{19}$, a także odgrywa istotną rolę $\mathrm{w}$ ramach ONZ. Tu warto zaznaczyć, że tworząc ten dokument podkreślano, iż będzie on oparty na istniejących już unormowaniach prawa międzynarodowego, a prace nad nim będą polegały na wyłuskaniu tych regulacji z tysięcy stron różnych konwencji ${ }^{20}$.

Do najistotniejszych, z punktu widzenia niniejszego opracowania, postanowień Wiodących zasad należą następujące:

Wprowadzenie, pkt 2:

Osoby przesiedlone wewnętrznie definiowane są jako osoby, które w dużych grupach nagle lub w sposób niespodziewany zostały zmuszone do ucieczki ze swoich domów lub stałych miejsc zamieszkiwania, co nastąpiło

sca zamieszkania w granicach każdego Państwa”, zaś art. 12 Międzynarodowego Paktu Praw Obywatelskich i Politycznych stanowi: „Każdy człowiek przebywający legalnie na terytorium jakiegokolwiek Państwa będzie miał prawo, w obrębie tego terytorium, do swobody poruszania się i wolności wyboru miejsca zamieszkania", Międzynarodowy Pakt Praw Obywatelskich i Politycznych, Dz. U. z 1977 r. Nr 38, poz. 167, http:// prawo.sejm.gov.pl/isap.nsf/download.xsp/WDU19770380167/T/D19770167L.pdf [dostęp: 27.01.2018 r.].

16 Na temat rozumienia terminu soft law, zob. B. Kuźniak, P. Turek, Soft law i quasi-soft law na przykładzie opinii Rady Konsultacyjnej Prokuratorów Europejskich, [w:] B. Kuźniak, M. Ingelevič-Citak, Ius cogens - soft law. Dwa bieguny prawa międzynarodowego publicznego, Kraków 2017, s. 234-236.

17 Zob. Dokument E/CN.4/1998/53/Add.2, http://www.un-documents.net/gpid. htm [dostęp: 13.03.2017 r.]; zob. także np. Н.I. Тищенко, Б.Ю. Піроцький, Внутрішньо переміщені особи в Україні як проблема сьогодення, „Молодий вчений” 2014, nr 10, s. 125.

18 Tu warto zaznaczyć, że Ch. Beyani - Przedstawiciel Sekretarza Generalnego ONZ ds. Praw Człowieka Osób Wewnętrznie Przesiedlonych - we wrześniu 2016 r. odwiedził Ukrainę, zob. United Nations Human Rights Office of the High Commissioner, Украина: Эксперт ООН по правал человека оценит прогресс в положении внутренне перемещенных лиu, http://www.ohchr.org/RU/NewsEvents/Pages/DisplayNews.aspx?NewsID=20432\&Lan$\mathrm{gID}=\mathrm{R}$ [dostęp: 13.03.2017 r.].

19 Zob. D. Heidrich-Hamera, Międzynarodowa ochrona uchodźców wewnętrznych, s. 67.

20 Zob. tamże, s. 67. 
w szczególności w rezultacie konfliktu zbrojnego ${ }^{21}$, przemocy wewnętrznej, systematycznego naruszania praw człowieka lub naturalnych i wywołanych działalnością człowieka katastrof, i nie przekroczyły uznanej przez wspólnotę międzynarodową granicy państwowej.

\section{Zasada 3}

Władze krajowe, które obejmują swoją jurysdykcją IDPs, mają obowiązek chronić uchodźców wewnętrznych i dostarczać im pomoc humanitarną. Są one w pierwszej kolejności odpowiedzialne za uchodźców wewnętrznych. [...]

\section{Zasada 4}

[...] Niektóre osoby przesiedlone wewnętrznie, takie jak np. dzieci, szczególnie pozbawione opieki dorosłych, kobiety w ciąży, kobiety z małymi dziećmi, kobiety będące głową gospodarstwa domowego, osoby niepełnosprawne oraz osoby starsze, będą uprawnione do takiej opieki i pomocy, jakiej wymaga ich sytuacja, i do takiego traktowania, które uwzględnia ich specyficzne potrzeby.

\section{Zasada 12}

[...] osoby te [uchodźcy wewnętrzni - B. K. i I. Z.] nie będą zamykane i przetrzymywane w obozach.

\section{Zasada 14}

Każda osoba wewnętrznie przesiedlona ma prawo do wolności poruszania się i wolności wyboru miejsca zamieszkania. [...]

\section{Zasada 15}

Osoby przesiedlone wewnętrznie mają prawo do [...] ochrony przed przymusowym powrotem lub przesiedleniem do miejsc, gdzie ich życie, bezpieczeństwo, wolność i/lub zdrowie byłyby zagrożone ${ }^{22}$.

Wiodące zasady są oparte na wiążących normach prawa międzynarodowego, w szczególności takich jak zawarte w Międzynarodowym Pakcie Praw Obywatelskich i Politycznych oraz Konwencji dotyczącej statusu uchodźców. Zasady wskazują i wyjaśniają, w jaki sposób unormowania wymienionych wyżej traktatów powinny być - przy uwzględnieniu spe-

${ }^{21}$ Tu warto dodać, że funkcjonuje w doktrynie pogląd, wedle którego do uchodźców wewnętrznych należy zaliczać jedynie osoby, które zostały zmuszone do ucieczki ze swoich domów lub stałych miejsc zamieszkiwania tylko w rezultacie konfliktu zbrojnego, a nie innych okoliczności, zob. E. Mooney, The Concept of Internal Displacement and the Case for Internally Displaced Persons as a Category of Concern, "Refugee Survey Quarterly” 2005, t. 24 , nr 3, s. 9 .

${ }_{22}$ Tłumaczenie, zob. D. Heidrich-Hamera, Międzynarodowa ochrona uchodźców wewnętrznych, s. 291 i nast. 
cyficznych potrzeb uchodźców wewnętrznych - stosowane w warunkach wewnętrznego przemieszczenia ${ }^{23}$.

\section{Dane statystyczne}

Jeżeli postawimy pytanie, czy społeczność międzynarodowa powinna zwrócić uwagę na taką kategorię osób jak uchodźcy wewnętrzni oraz czy - pomimo obowiązującego zakazu interwencji w sprawy wewnętrzne państw - uzasadnionym jest by prawo międzynarodowe publiczne obejmowało normy dedykowane ich ochronie, to wydaje się, iż w pierwszej kolejności warto pokazać skalę zjawiska.

Zgodnie z danymi ONZ, już w 2007 r. globalna liczba osób wewnętrznie przesiedlonych wynosiła 24,5 miliona. Na tę liczbę składali się uchodźcy wewnętrzni przede wszystkim w takich państwach jak: Kolumbia, Algieria, Wybrzeże Kości Słoniowej, Kongo, Uganda, Kenia, Somalia, Turcja, Irak, Syria ${ }^{24}$. Pod koniec 2014 r. odnotowano aż około 38 milionów osób wewnętrznie przesiedlonych ${ }^{25}$, przy czym na $60 \%$ tej liczby składali się uchodźcy wewnętrzni w Kongo, Iraku, Nigerii, Sudanie i Syrii. Irak posiadał wówczas 2,2 miliona uchodźców wewnętrznych, zaś największa ich liczba dotyczyła Syrii (7,6 miliona osób, co stanowiło 40\% ludności państwa ${ }^{26}$. Urząd Wysokiego Komisarza Narodów Zjednoczonych ds. Uchodźców (United Nations High Commissioner for Refugees - UNHCR) podaje informację, iż na koniec 2015 r. ogólna liczba uchodźców wewnętrznych wynosiła około 40 milionów osób ${ }^{27}$.

Również Europa stała się miejscem istnienia uchodźców wewnętrznych, co zostało spowodowane przywołanymi we wstępie wydarzeniami na Ukrainie.

${ }_{23}$ Zob. O.I. Котляр, Керівні принципи з питань щзодо переміщення осіб всередині країни як відображення норм міжнародного права, [w:] О.Я. Рогач, М.В. Савчин, М.В. Менджул (red.), Механізм забезпечення прав внутрішньо переміщених осіб: національний та міжнародний аспекти, Ужгород 2017, s. 23.

${ }_{24}$ UN High Commissioner for Refugees (UNHCR), Internally Displaced People. Questions \& Answers, September 2007, UNHCR / MRPI / Q\&A A-3 / ENG 1, http://www.refworld.org/ docid/47a7078e1.html [dostęp: 21.02.2017 r.].

25 Internal Displacement Monitoring Centre, Global Overview 2015. People Internally Displaced by Conflict and Violence, http://www.internal-displacement.org/assets/library/ Media/201505-Global-Overview-2015/20150506-global-overview-2015-en.pdf, s. 9 [dostęp: 21.02.2017 r.].

26 UN High Commissioner for Refugees (UNHCR), Internally Displaced People, http://www.unhcr.org/internally-displaced-people.html [dostęp: 21.02.2017 r.].

${ }_{27}$ Internal Displacement Monitoring Centre, http://www.internal-displacement.org/ globalreport2016/ [dostęp: 21.02.2017 r.]. 
Wedle danych z 2015 r., na ogólną liczbę obywateli Ukrainy (44 800000 osób) przypadło aż 1679000 osób, które były uchodźcami wewnętrznymi ${ }^{28}$ (co oznacza aż 1 uchodźcę wewnętrznego na 27 obywateli Ukrainy wolnych od tego problemu). W marcu 2017 r., zgodnie z informacją Ministerstwa Polityki Społecznej Ukrainy, ogólna liczba uchodźców wewnętrznych w czasie konfliktu zbrojnego wynosiła 1623726 osób $^{29}$. Wedle danych jakimi dysponujemy (dane za 2015 r.), więcej niż połowa tych osób zaczęła mieszkać w rejonach bezpiecznych, niemniej sąsiadujących ze swoim pierwotnym miejscem zamieszkania, przy czym znaczny procent tych osób (około 80\%) stanowią emeryci.

W 2016 r. na Ukrainie utworzono ministerstwo zajmujące się sprawą tymczasowo okupowanych terytoriów i uchodźcami wewnętrznymi (Міністерство з питань тимчасово окупованих територій та внутрінньо переміщених осіб). Na dzień dzisiejszy trudno jeszcze ocenić działalność tego organu władzy i jego współpracę z innymi ministerstwami, które również przejawiają swą aktywność na rzecz uchodźców, niemniej już dziś można krytycznie ocenić na przykład dostęp do aktualnych danych statystycznych (na portalu internetowym ministerstwa znajdują się głównie linki przekierowujące do prawodawstwa dotyczącego ochrony uchodźców), nie wiadomo także jak przebiegają prace ministerstwa nad ustaleniem aktualnych informacji dotyczących położenia omawianej kategorii osób ${ }^{30}$.

\section{Prawodawstwo Ukrainy}

Jeżeli chodzi o regulacje prawne dotyczące uchodźców niemających charakteru osób wewnętrznie przesiedlonych, to w 2012 r. Rada Najwyższa Ukrainy (Верховна Pada) przyjęła ustawę o uchodźcach i osobach potrzebujących ochrony uzupełniającej lub czasowej (Закон України «Про біженців та осіб, які потребують додаткового або тимчасового захисту») ${ }^{31}$.

Warto podkreślić, iż definicja uchodźców zawarta w tej ustawie odpowiada postanowieniom konwencji z $1951 \mathrm{r} .^{32}$

${ }^{28}$ Internal Displacement Monitoring Centre, http://www.internal-displacement.org/ database/country/?iso3=ukr [dostęp: 13.03.2017 r.].

29 Міністерство социільної політики Украӥни, http://www.msp.gov.ua/news/12682. html [dostęp: 13.03.2017 r.].

30 Офіційна веб-сторінка Міністерства з питань тимчасово окупованих територій та внутрішньо переміщених осіб України, http://mtot.gov.ua/ [dostęp: 13.03.2017 r.].

31 Відомості Верховної Ради України (ВВР), 2012, nr 16, s. 146, http://zakon0.rada.gov. ua/laws/show/3671-17 [dostęp: 12.03.2017 r.].

32 Zob. Ю. Аушпієнко, Конституційно-правовий статус біжениів та внутрішньо переміщених осіб в Україні, „Підприємництво, господарство і право” 2017, nr 2, s. 189. 
Стаття 1 [...] біженець - особа, яка не є громадянином України і внаслідок обгрунтованих побоювань стати жертвою переслідувань за ознаками раси, віросповідання, національності, громадянства (підданства), належності до певної соціальної групи або політичних переконань перебуває за межами країни своєї громадянської належності та не може користуватися захистом цієї країни або не бажає користуватися цим захистом внаслідок таких побоювань, або, не маючи громадянства (підданства) і перебуваючи за межами країни свого попереднього постійного проживання, не може чи не бажає повернутися до неї внаслідок зазначених побоювань.

Artykuł 1 [...] uchodźca - osoba, która nie jest obywatelem Ukrainy i któ$\mathrm{ra}, \mathrm{z}$ powodu uzasadnionej obawy przed prześladowaniem z powodu swojej rasy, religii, narodowości, obywatelstwa, przynależności do określonej grupy społecznej lub z powodu przekonań politycznych, przebywa poza granicami państwa, którego jest obywatelem i nie może lub nie chce z powodu tych obaw korzystać z ochrony tego państwa albo która nie mając żadnego obywatelstwa i znajdując się poza państwem swojego dawnego stałego zamieszkania, nie może lub nie chce $\mathrm{z}$ powodu tych obaw do niego powrócić ${ }^{33}$.

Powyższa ustawa zawiera $\mathrm{w}$ sobie także zasadę non-refoulement (art. 3 ustawy ${ }^{34}$ ).

Natomiast, jeśli idzie o problem uchodźców wewnętrznych na Ukrainie, to w reakcji na aneksję Krymu oraz konflikt zbrojny na wschodzie tego państwa, parlament Ukrainy (Верховна Pada) i rząd Ukrainy (Кабінет Miнicmpiв) przyjęły cały szereg aktów prawnych mających na celu uregulowanie sytuacji osób wewnętrznie przesiedlonych i ochronę ich praw ${ }^{35}$. Są to wymienione niżej źródła prawa ukraińskiego:

Ustawa o zabezpieczeniu praw i wolności osób wewnętrznie przesiedlonych (2014 r.) - Закон України „Про забезпечення прав і свобод внутрішньо переміщених осіб" 36 .

1) W ustawie tej znajdują się postanowienia wyraźnie korespondujące z międzynarodowymi normami typu soft law poświęconymi problematyce

33 Tłumaczenie na j. polski: B. Kuźniak, I. Zeman.

34 Стаття 3. [...] Біженець чи особа, яка потребує додаткового захисту або якій надано тимчасовий захист, не може бути вислана або примусово повернута до країни, де їх життю або свободі загрожуе небезпека за ознаками раси, віросповідання, національності, громадянства (підданства), належності до певної соціальної групи або політичних переконань, а також з інших причин, що визнаються міжнародними договорами чи міжнародними організаціями, учасниками яких є Україна, як такі, що не можуть бути повернуті до країн походження.

35 Na ten temat zob. w szczególności, I.M. Подюжин, Гарантії прав внутрішньо переміщених осіб, [w:] О.Я. Рогач, М.В. Савчин, М.В. Менджул (red.), Механізм забезпечення прав внутрішньо переміщених осіб: націіональний та міжнародний аспекти, Ужгород 2017, s. 103.

36 Відомості Верховної Ради України (ВВР), 2015, nr 1, s. 1, http://zakon2.rada.gov.ua/ laws/show/1706-18 [dostęp: 12.03.2017 r.]. 
uchodźców wewnętrznych, czyli z Wiodącymi zasadami przesiedleń wewnątrzpaństwowych. Na szczególną uwagę zasługuje ustawowa definicja osoby wewnętrznie przesiedlonej, która to definicja jest spójna z cytowanymi wyżej postanowieniami pkt 2 Wprowadzenia do Zasad.

Art. 1 ww. ustawy:

Wewnętrznie przesiedloną osobą jest osoba będąca obywatelem Ukrainy, cudzoziemcem lub osobą bez obywatelstwa, która przebywa legalnie na Ukrainie i ma prawo do stałego pobytu na Ukrainie. Ta osoba była zmuszona do opuszczenia miejsca swojego zamieszkania w celu uniknięcia negatywnych skutków konfliktów zbrojnych, tymczasowej okupacji, naruszeń praw człowieka oraz katastrof naturalnych lub o charakterze technicznym ${ }^{37}$.

Powyższa ustawa zawiera w sobie także zasadę non-refoulement ${ }^{38}$. Z innych, bardziej istotnych postanowień, warto także wskazać co następuje: art. 4 ustawy reguluje procedurę rejestracji uchodźców wewnętrznych; art. 7 zapewnia prawa zarejestrowanych uchodźców w zakresie zatrudnienia, emerytury, obowiązkowych ubezpieczeń społecznych, świadczeń socjalnych i edukacji; art. 8 gwarantuje wyborcze prawa tych osób; zaś art. 9 zawiera postanowienia gwarantujące bezpłatne, tymczasowe zakwaterowania zarejestrowanych uchodźców wewnętrznych na okres do sześciu miesięcy po rejestracji. Ustawa zapewnia też m.in. pomoc w zakresie zaopatrzenia medycznego oraz rekrutacji dzieci do przedszkoli i szkół.

2) Ustawa o zabezpieczeniu praw i wolności obywateli i ich statusie prawnym na tymczasowo okupowanym terytorium Ukrainy (2014 r.) Закон України „Про забезпечення прав і свобод громадян та правовий режим на тимчасово окупованій території Украӥни"з9.

Ustawa ta m.in. stanowi, iż tymczasowo okupowane terytorium jest integralną częścią Ukrainy i działa tam ukraińskie ustawodawstwo. Za

37 Tłumaczenie na j. polski: B. Kuźniak, I. Zeman. Стаття 1. [...] Внутрішньо переміщеною особою е громадянин України, іноземець або особа без громадянства, яка перебуває на території України на законних підставах та має право на постійне проживання в Україні, яку змусили залишити або покинути своє місце проживання у результаті або $з$ метою уникнення негативних наслідків збройного конфлікту, тимчасової окупації, повсюдних проявів насильства, порушень прав дюдини та надзвичайних ситуацій природного чи техногенного характеру.

38 Стаття 3. [...] Громадянин України, іноземець або особа без громадянства, яка перебуває на території України на законних підставах та має право на постійне проживання в Україні, за обставин, визначених у статті 1 цього Закону, має право на захист від примусового внутрішнього переміщення або примусового повернення на покинуте місце проживання.

39 Відомості Верховної Ради Украйни (ВВР), 2014, nr 26, s. 892, http://zakon2.rada.gov. ua/laws/show/1706-18 [dostęp: 12.03.2017 r.]. 
początkową datę tymczasowej okupacji przyjęto przy tym dzień 20 lutego 2014 r. ${ }^{40} \mathrm{~W}$ art. 5 ustawy zatwierdzono zaś, że wymuszona automatyczna zmiana obywatelstwa obywateli Ukrainy zamieszkałych na tymczasowo okupowanym terytorium, na obywatelstwo rosyjskie, nie jest uznawana przez Ukrainę i nie jest podstawą do utraty obywatelstwa Ukrainy ${ }^{41}$.

3) Ustawa o stworzeniu wolnej strefy ekonomicznej „Krym” i o specyfice działalności gospodarczej na tymczasowo okupowanym terytorium Ukrainy (2014 r.) - Закон України „Про створення вільної економічної зони «Крим» та про особливості здійснення економічної діяльності на тимчасово окупованій території України"42.

4) Ustawa o tymczasowych środkach na czas operacji antyterrorystyczпеј (2014 r.) - Закон Украӥни "Про тимчасові заходи на період проведення антитерористичної операції"43.

5) Decyzja Gabinetu Ministrów o rejestracji osób wewnętrznie przesiedlonych (2014 r.) - Постанова Кабінету Міністрів Украйни "Про облік внутрішньо переміщених осіб" 44 .

6) Decyzja Gabinetu Ministrów o przyznaniu comiesięcznej pomocy osobom wewnętrznie przesiedlonym dla pokrycia wydatków na pobyt oraz usługi komunalne (2014 r.) - Постанова Кабінету Міністрів України „Про надання щомісячної адресної допомоги внутрішньо переміщеним особам для покриття витрат на проживання, в тому числі на оплату житловокомунальних послуг"

Decyzja powyższa określiła kwoty pomocy państwowej, jakie miesięcznie może otrzymać osoba lub rodzina (emeryt albo dziecko - 884 hrywien (UAH); inwalida - $1544 U A H$; osoba zdolna do pracy - $442 U A H$, przy czym ogólna suma pomocy na rodzinę nie może przekraczać $2400 U A H)$.

7) Decyzja Gabinetu Ministrów dotycząca porządku wjazdu i wyjazdu z tymczasowo okupowanego terytorium (2015 r.) - Постанова Кабінету

40 Стаття 1. [...] Тимчасово окупована територія України (далі - тимчасово окупована територія) є невід'ємною частиною території України, на яку поширюється дія Конституції та законів України. 2. Датою початку тимчасової окупації є 20 лютого 2014 року.

41 Стаття 5. [...] Примусове автоматичне набуття громадянами України, які проживають на тимчасово окупованій території, громадянства Російської Федерації не визнається Україною та не є підставою для втрати громадянства України.

42 Відомості Верховної Ради України (ВВР), 2014, nr 43, s. 2030, http://zakon2.rada.gov. ua/laws/show/1636-18 [dostęp: 12.03.2017 r.].

43 Відомості Верховної Ради України (ВВР), 2014, nr 44, s. 2040, http://zakon2.rada.gov. ua/laws/show/1669-18 [dostęp: 12. 03.2017 r.].

44 Офіційний вісник України, 2014, nr 81, s. 2296, http://zakon3.rada.gov.ua/laws/show/509-2014-\%D0\%BF [dostęp: 12. 03.2017 r.].

45 Офіиійний вісник України, 2014, nr 80, s. 2271, http://zakon2.rada.gov.ua/laws/show/505-2014-\%D0\%BF [dostęp: 12. 03.2017 r.]. 
Міністрів Украйни „Про затвердження Порядку в'їзду на тимчасово окуповану територію України та виїзду з неї"46.

\section{Konkluzje}

Rekapitulując można przyznać, że działania faktyczne i prawne podjęte na Ukrainie stanowią adekwatny przykład wpływu regulacji międzynarodowych, w tym regulacji prawnych o charakterze soft law, na przestrzeganie praw człowieka przez państwo. W szczególności, co do sytuacji uchodźców wewnętrznych, warto podkreślić, że Ukraina nie zamyka się na pomoc i oddziaływanie płynące z zewnątrz - tu dobrym przykładem jest wizyta w tym państwie Specjalnego Sprawozdawcy ds. Praw Człowieka Osób Wewnętrznie Przesiedlonych we wrześniu 2016 r. Również, zarysowane wyżej wewnętrzne regulacje prawne dotyczące uchodźców oraz IDPs pozostają odpowiednio w korelacji z konwencją z 1951 r. i z Wiodącymi zasadami przesiedleń wewnątrzpaństwowych. Godnym zaznaczenia wydaje się fakt, iż Ukraina (drogą prawodawstwa wewnętrznego) w sposób spójny z Zasadami, definiuje uchodźców wewnętrznych, a także odpowiednio do Zasad różnicuje ich sytuację (emeryci, dzieci, inwalidzi, osoby zdolne do pracy), czy też nie podejmuje żadnych prób umieszczania wewnętrznych przesiedleńców w specjalnych obozach itd. - szanując ich wolność wyboru co do miejsca zamieszkania. Niezwykle istotnym jawi się także fakt, iż, w aspekcie generalnym, państwo to nie odżegnuje się od tego co zapisano w Zasadach, a mianowicie, iż to ono w pierwszej kolejności jest odpowiedzialne za uchodźców wewnętrznych.

Słowa kluczowe: prawa człowieka, uchodźcy, uchodźcy wewnętrzni, aneksja Krymu, konflikt zbrojny na wschodzie Ukrainy

\section{Bibliografia}

Heidrich-Hamera D., Międzynarodowa ochrona uchodźców wewnętrznych. Aspekty prawne i praktyka, Warszawa 2005.

Kotlâr O.Ì., Kerìvì principi z pitan' ŝodo peremiŝsennâ osib vseredinì kraïni âk vìdobražennâ norm mižnarodnogo prava, [w:] O.Â. Rogač, M.V. Savčin, M.V. Mendžul (red.),

46 Офіційний вісник України, 2015, nr 46, s. 1485, http://zakon0.rada.gov.ua/laws/show/367-2015-\%D0\%BF [dostęp: 12.30.2017 r.]. 
Mehanizm zabezpečennâ prav vnutrišn'o peremî̂enih osib: nacional'nij ta mižnarodnij aspekti, Užgorod 2017, s. 19-30.

Krahmal'ova K.O., Pravove zabezpečennâ statusu vnutrǐ̌n'o peremiŝenih osib v Ukraïnì, Naukovij visnik Hersons'kogo deržavnogo unìversitetu, "Seriâ Ûridičnì nauki” 2016, t. 2, s. 43-45.

Kuźniak B., P. Turek, Soft law i quasi-soft law na przykładzie opinii Rady Konsultacyjnej Prokuratorów Europejskich, [w:] B. Kuźniak, M. Ingelevič-Citak, Ius cogens - soft law. Dwa bieguny prawa międzynarodowego publicznego, Kraków 2017, s. 229-238.

Lušpiênko Û., Konstitucìno-pravovij status bižencìv ta vnutrǐšn'o peremiŝenih osib v Ukraïnì, „Pidpriêmnictvo, gospodarstvo ì pravo” 2017, nr 2, s. 188-193.

Maciąg M., Vopros lic, peremeŝennyh vnutri strany, $v$ sovremennom mire i strategii ego rešeniâ, [w:] B. Kuźniak (red.), Wybrane zagadnienia współczesnego prawa międzynarodowego publicznego ze szczególnym uwzględnieniem niektórych aspektów funkcjonowania organizacji międzynarodowych, Kraków 2016, s. 62-70.

Mooney E., The Concept of Internal Displacement and the Case for Internally Displaced Persons as a Category of Concern, „Refugee Survey Quarterly” 2005, t. 24, nr 3, s. 9-26.

Nadraga V.Ì., Problemi vimušenoï vnutrì̌n'oï migracï naselennâ v kontekstì koncepciï «suspil'stva riziku», „Ukraïns'kij socium” 2015, nr 1, s. 134-141.

Polûžin İ.M., Garantï prav vnutrišn'o peremiŝenih osib, [w:] O.Â. Rogač, M.V. Savčin, M.V. Mendžul (red.), Mehanìm zabezpečennâ prav vnutrišn'o peremiŝenih osib: nacional'nij ta mižnarodnij aspekti, Užgorod 2017, s. 100-117.

Sìrant M.M., Bižencì ta vnutrišn'o peremiŝeni osobi: spìvvìdnošennâ ponât', „Mitna sprava" 2015, nr 2, s. 154-159.

Tiŝenko N.İ., Vnutrišn'o peremiŝeni osobì v Ukraïnì âk problema s'ogodennâ, „Molodij včenij" 2014, nr 10, s. 124-126.

Woyciechowska I., Uchodźcy, [w:] J. Simonides (red.), Organizacja Narodów Zjednoczonych. Bilans i perspektywy, Warszawa 2006, s. 349-364.

\section{INTERNALLY DISPLACED PERSONS IN UKRAINE - THE IMPACT OF PUBLIC INTERNATIONAL LAW ON HUMAN RIGHTS PROTECTION}

\section{$S \mathbf{u ~ m ~ m ~ a ~ r ~ y ~}$}

The article presents the influence of international treaties and international institutions on the observance of human rights in Ukraine. The first part discusses the issues of international legal protection of refugees and the issue of internally displaced persons. The second part presents the scale of the mentioned phenomenon in Ukraine. The third part provides relevant solutions to the problem in the Ukrainian legislation. On the basis of a holistic analysis of the work conclusions were formulated. 
Key words: human rights, refugees, internally displaced persons, annexation of Crimea, armed conflict in the east of Ukraine

\section{СИТУАЦИЯ ВНУТРЕННИХ БЕЖЕНЦЕВ НА УКРАИНЕ В СВЕТЕ МЕЖДУНАРОДНО-ПРАВОВЫХ РЕГУ ЛИРОВАНИИ}

$$
\text { P е } 3 \text { ю м е }
$$

Текст показывает вдияние международных договоров и международных учреждений на права человека в Украине. В первой части оговорены вопросы из области международно-правовой охраны беженцев и представлена проблематика внутренних беженцев. В другой части представлена шкала упомянутого явления в Украине. В третьей части продемонстрированы соответствующие решения украинского права. Все исследования были увенчаны выводами.

Ключевые слова: права человека, беженцы, внутренние беженцы, аннексия Крыма, вооруженный конфдикт на востоке Украины 